\title{
Maternal Thyroid Disorders and Risk of Neonatal Seizure: Current Perspective
}

\author{
Ahmed R.G* \\ Division of Anatomy and Embryology, Zoology Department, Faculty of Science, Beni-Suef University, Beni- \\ Suef, Egypt
}

*Corresponding Author: Ahmed R.G, Division of Anatomy and Embryology, Zoology Department, Faculty of Science, Beni-Suef University, Beni-Suef, Egypt, Email: ahmedragab08@gmail.com

\section{HYPOTHESIS}

The maternal hypothalamic-pituitary-thyroid axis (HPTA) is required for the development of all biological systems (Ahmed, 2011, 2012a,b, 2013, 2014, 2015a-c, 2016a-d, 2017a-u \& 2018a,b; Ahmed et al., 2010, 2013a,b, 2014, 2015a,b \&2018a,b; Ahmed and Incerpi, 2013; Van Hercket al., 2013; Ahmed andElGareib, 2014,Incerpi et al., 2014; Candelotti et al., 2015; De Vito et al., 2015; El-Ghareeb et al., 2016; Ahmed and El-Gareib, 2017), especially the developing nervous system (proliferation, differentiation and migration of neurons, astrocytes, oligodendrocytes, microglia, synaptogenesis, and myelination) (Zoeller et al., 2002; Zoeller, 2004; Pacheco-Rosado et al., 2005; Santisteban and Bernal, 2005; Gilbert and Sui, 2006; Hamanna et al., 2006; Zamoner et al., 2006; Hogan et al., 2007; Ahmed et al., 2008; Carlé et al., 2011; Andersen et al., 2013; Ahmed and El-Gareib, 2017).

On the other hand, numerous investigations illustrated the association of the maternal thyroid disorders with the neonatal neurocognitive maldevelopment (Haddow et al., 1999; Klein et al., 2001; Pop et al., 2003; Carlé et al., 2006 \& 2011; Lazarus et al., 2012). Moreover, Andersen et al. (2013) reported that the risk of seizure (excessive discharge of a set of neurons) in the neonates and subtle changes in brain might be increased during the maternal hypothyroidism or hyperthyroidism. This observation is reinforced by Koromilas et al. (2010) who reported that there are several alterations in the structural and functional of developing hippocampus during the hypothyroid state, and Asami et al., (1998) who undertook that the congenital hypothyroidism can increase the risk of febrile seizures. More interestingly, there are several causes for the neonatal seizures such as hemorrhage, stroke, perinatal hypoxia-ischemia, metabolic disorders, infections, hypernatremia, asphyxia, intracranial hemorrhage, hypocalcemia, and hypoglycemia (Scher, 2000 \& 2003; Kawakami et al., 2002; Caravale et al., 2003; Zupanc, 2004; Manoel and Demelo, 2006; Eghbalian et al., 2007). More importantly, the discrepancy diagnosis for the seizure during the gestation includes the following (Jaigobin and Silver, 2000; EURAP Study Group, 2006; Lockhart and Baysinger, 2007; Contag et al., 2009; Allais et al, 2010; Banach et al., 2010; Noori and Dhanjal, 2011)eclampsia, electrolyte imbalances (hypocalcaemia and hyponatraemia), cerebral thrombosis, metabolic disorders (hypoglycaemia), stroke, and intracranial mass lesion. In general, the dysfunction in the maternal thyroid during the early pregnancy can alter the activities of ion channels (Ahmed and Incerpi, 2013), metabolic enzymes (Ahmed et al., 2008), neurotransmitter receptors (Ahmed et al., 2010) and transporters (Ahmed, 2012b \& $2015 b$ ) in the developing brain. This canalterthe characteristic of the nerve cells, decrease the synchronization and cause the neonatal seizure and several neurocognitive problems.

From the above considerations, the present observations suggested that the maternal THs show vital actions in the developing brain during the prenatal and postnatal periods. The maternal thyroid dysfunctions may directly or indirectly disturb the development (morphogenesis) of the brain. This disturbance may cause neonatal seizure and neurocognitive defects. Thus, the treatment can be required before the gestation to avoid these disorders. This would provide an earlier advantage to maximizing the neurological outcome. Several researches are desired to follow the impacts of maternal thyroid dysfunctions on the neonatal seizure, febrile seizure, and epilepsy before, during, and after the gestation. 


\section{REFERENCES}

[1] Ahmed, O.M., Abd El-Tawab, S.M., Ahmed, R.G., 2010. Effects of experimentally induced maternal hypothyroidism and hyperthyroidism on the development of rat offspring: I- The development of the thyroid hormonesneurotransmitters and adenosinergic system interactions. Int. J. Dev. Neurosci. 28, 437-454.

[2] Ahmed, O.M., Abd El-Tawab, S.M., Ahmed, R.G., 2010. Effects of experimentally induced maternal hypothyroidism and hyperthyroidism on the development of rat offspring: I- The development of the thyroid hormonesneurotransmitters and adenosinergic system interactions. Int. J. Dev. Neurosci. 28, 437-454.

[3] Ahmed, O.M., Ahmed, R.G., 2012. Hypothyroidism. In A New Look At Hypothyroidism. Dr. D. Springer (Ed.), ISBN: 978-953-51-0020-1), In Tech Open Access Publisher, Chapter 1, pp. 1-20.

[4] Ahmed, O.M., Ahmed, R.G., El-Gareib, A.W., El-Bakry, A.M., Abd El-Tawaba, S.M., 2012. Effects of experimentally induced maternal hypothyroidism and hyperthyroidism on the development of rat offspring: II-The developmental pattern of neurons in relation to oxidative stress and antioxidant defense system. Int. J. Dev. Neurosci. 30, 517-537.

[5] Ahmed, O.M., El-Gareib, A.W., El-bakry, A.M., Abd El-Tawab, S.M., Ahmed, R.G., 2008. Thyroid hormones states and brain development interactions. Int. J. Dev. Neurosci. 26(2), 147-209. Review.

[6] Ahmed, R.G., 2011. Perinatal 2, 3, 7, 8tetrachlorodibenzo-p-dioxin exposure alters developmental neuroendocrine system. Food Chem. Toxicology, 49, 1276-1284.

[7] Ahmed, R.G., 2012a. Maternal-newborn thyroid dysfunction. In the Developmental Neuroendocrinology, pp. 1-369. Ed R.G. Ahmed. Germany: LAP LAMBERT Academic Publishing GmbH \& Co KG.

[8] Ahmed, R.G., 2012b. Maternal-fetal thyroid interactions, Thyroid Hormone, Dr. N.K. Agrawal (Ed.), ISBN: 978-953-51-0678-4, In Tech Open Access Publisher, Chapter 5, pp. 125-156.

[9] Ahmed, R.G., 2013. Early weaning PCB 95 exposure alters the neonatal endocrine system: thyroid adipokine dysfunction. J. Endocrinol. 219 (3), 205-215.

[10] Ahmed, R.G., 2014. Editorial: Do PCBs modify the thyroid-adipokine axis during development? Annals Thyroid Res. 1(1), 11-12.

[11] Ahmed, R.G., 2015a. Chapter 1: Hypothyroidism and brain development. In advances in hypothyroidism treatment. Avid Science Borsigstr.9, 10115 Berlin, Berlin, Germany. Avid Science Publications level 6, Melange Towers,
Wing a, Hitec City, Hyderabad, Telangana, India. pp. 1-40.

[12] Ahmed, R.G., 2015b. Hypothyroidism and brain developmental players. Thyroid Research J. 8(2), 1-12.

[13] Ahmed, R.G., 2015c. Editorials and Commentary: Maternofetal thyroid action and brain development. J. of Advances in Biology; 7(1), 1207-1213.

[14] Ahmed, R.G., 2016a. Gestational dexamethasone alters fetal neuroendocrine axis. Toxicology Letters, 258, 46-54.

[15] Ahmed, R.G., 2016b. Neonatal polychlorinated biphenyls-induced endocrine dysfunction. Ann. Thyroid. Res. 2 (1), 34-35.

[16] Ahmed, R.G., 2016c. Maternal iodine deficiency and brain disorders. Endocrinol. Metab.Syndr.5, 223. http://dx. doi.org/10.4172/ 2161-1017.1000223.

[17] Ahmed, R.G., 2016d. Maternal bisphenol A alters fetal endocrine system: Thyroid adipokine dysfunction. Food Chem. Toxicology, 95, 168-174.

[18] Ahmed, R.G., 2017a. Developmental thyroid diseases and GABAergic dysfunction. EC Neurology 8.1, 02-04.

[19] Ahmed, R.G., 2017b. Hyperthyroidism and developmental dysfunction. Arch Med. 9, 4.

[20] Ahmed, R.G., 2017c. Anti-thyroid drugs may be at higher risk for perinatal thyroid disease. EC Pharmacology and Toxicology 4.4, 140142.

[21] Ahmed, R.G., 2017d. Perinatal hypothyroidism and cytoskeleton dysfunction. Endocrinol MetabSyndr 6, 271.doi:10.4172/2161-1017. 1000271

[22] Ahmed, R.G., 2017e.Developmental thyroid diseases and monoaminergic dysfunction. Advances in Applied Science Research 8(3), 01-10.

[23] Ahmed, R.G., 2017f.Hypothyroidism and brain development. J. Anim Res Nutr.2 (2), 13.

[24] Ahmed, R.G., 2017g. Antiepileptic drugs and developmental neuroendocrine dysfunction: Every why has A Wherefore. Arch Med 9(6), 2.

[25] Ahmed, R.G., 2017h. Gestational prooxidantantioxidant imbalance may be at higher risk for postpartum thyroid disease. Endocrinol MetabSyndr 6, 279. doi:10.4172/2161-1017. 1000279 .

[26] Ahmed, R.G., 2017i. Synergistic actions of thyroid-adipokines axis during development. Endocrinol MetabSyndr 6, 280.doi:10.4172/ 2161-1017.1000280.

[27] Ahmed, R.G., 2017j. Thyroid-insulin dysfunction during development. International Journal of Research Studies in Zoology 3(4), 73-75. DOI: http://dx.doi.org/10.20431/2454-941X.0304010 
[28] Ahmed, R.G., 2017k. Developmental thyroid diseases and cholinergic imbalance. International Journal of Research Studies in Zoology 3(4), 70-72. DOI: http://dx.doi.org/ 10.20431/2454941X.0304009.

[29] Ahmed, R.G., 20171. Thyroid diseases and developmental adenosinergic imbalance. Int $\mathbf{J}$ ClinEndocrinol 1(2), 053-055.

[30] Ahmed, R.G., 2017m.Maternal anticancer drugs and fetal neuroendocrine dysfunction in experimental animals. Endocrinol MetabSyndr 6, 281.doi:10.4172/2161-1017.1000281.

[31] Ahmed, R.G., 2017n. Letter: Gestational dexamethasone may be at higher risk for thyroid disease developing peripartum. Open Journal of Biomedical \& Life Sciences (Ojbili) 3(2), 01-06.

[32] Ahmed, R.G., 2017o.Deiodinases and developmental hypothyroidism. EC Nutrition 11.5, 183-185.

[33] Ahmed, R.G., 2017p.Maternofetal thyroid hormones and risk of diabetes. Int. J. of Res. Studies in Medical and Health Sciences 2(10), 18-21.

[34] Ahmed, R.G., 2017r.Association between hypothyroidism and renal dysfunctions. International Journal of Research Studies in Medical and Health Sciences 2(11), 1-4.

[35] Ahmed, R.G., 2017s.Maternal hypothyroidism and lung dysfunction. International Journal of Research Studies in Medical and Health Sciences 2(11), 8-11.

[36] Ahmed, R.G., 2017t.Endocrine disruptors; possible mechanisms for inducing developmental disorders. International journal of basic science in medicine (IJBSM) 2(4), $\mathrm{xx}$-xx. (in press)

[37] Ahmed, R.G., 2017u.Maternal thyroid hormones trajectories and neonatal behavioral disorders. ARC Journal of Diabetes and Endocrinology 3(2), 18-21.

[38] Ahmed, R.G., 2018a. Maternal hypothyroidism and neonatal testicular dysfunction. International Journal of Research Studies in Medical and Health Sciences 3(1), 8-12.

[39] Ahmed, R.G., 2018b. Maternal thyroid disorders and bone maldevelopment: Are you ready to take risks for your offspring? J Pharma PharmaSci (JPPS) in press. DOI: 10.29011/ 2574-7711. 100058.

[40] Ahmed, R.G., Abdel-Latif, M., Ahmed F., 2015a.Protective effects of GM-CSF in experimental neonatal hypothyroidism. International Immunopharmacology 29, 538-543.

[41] Ahmed, R.G., Abdel-Latif, M., Mahdi, E., ElNesr, K., 2015b. Immune stimulation improves endocrine and neural fetal outcomes in a model of maternofetal thyrotoxicosis. Int. Immunopharmacol. 29, 714-721.

[42] Ahmed, R.G., Davis, P.J., Davis, F.B., De Vito, P., Farias, R.N., Luly, P., Pedersen, J.Z., Incerpi, S., 2013a. Nongenomic actions of thyroid hormones: from basic research to clinical applications. An update. Immunology, Endocrine \& Metabolic Agents in Medicinal Chemistry, 13(1), 46-59.

[43] Ahmed, R.G., El-Gareib, A.W. 2014.Lactating PTU exposure: I- Alters thyroid-neural axis in neonatal cerebellum. Eur. J. of Biol. and Medical Sci. Res. 2(1), 1-16.

[44] Ahmed, R.G., El-Gareib, A.W., 2017.Maternal carbamazepine alters fetal neuroendocrinecytokines axis. Toxicology 382, 59-66.

[45] Ahmed, R.G., El-Gareib, A.W., Incerpi, S., 2014. Lactating PTU exposure: II- Alters thyroid-axis and prooxidant-antioxidant balance in neonatal cerebellum. Int. Res. J. of Natural Sciences 2(1), 1-20.

[46] Ahmed, R.G., El-Gareib, A.W., Shaker, H.M., 2018a.Gestational 3,3', 4,4', 5-pentachloro biphenyl (PCB 126) exposure disrupts fetoplacental unit: Fetal thyroid-cytokines dysfunction. Life Sciences 192, 213-220.

[47] Ahmed, R.G., Incerpi, S., 2013. Gestational doxorubicin alters fetal thyroid-brain axis. Int. J. Devl. Neuroscience 31, 96-104.

[48] Ahmed, R.G., Incerpi, S., Ahmed, F., Gaber, A., 2013b. The developmental and physiological interactions between free radicals and antioxidant: Effect of environmental pollutants. J. of Natural Sci. Res. 3(13), 74-110.

[49] Ahmed, R.G., Walaa G.H., Asmaa F.S., 2018b.Suppressive effects of neonatal bisphenol A on the neuroendocrine system. Toxicology and Industrial Health Journal (in press).

[50] Allais, G., Gabellari, I.C., Borgogno, P., de Lorenzo, C., Benedetto, C., 2010. The risks of women with migraine during pregnancy. NeurolSci 31, S59-61.

[51] Andersen, S.L., Laurberg, P., Wu, C.S., Olsen, J., 2013. Maternal thyroid dysfunction and risk of seizure in the child: A Danish nationwide cohort study. Journal of Pregnancy 1-10.

[52] Asami, T., Sasagawa, F., Kyo, S., Asami, K., Uchiyama, M., 1998.Incidence of febrile convulsions in children with congenital hypothyroidism. Acta Paediatrica 87(6), 623626.

[53] Banach, R., Boskovic, R., Einarson, T., Koren, G., 2010. Long-term developmental outcome of children of women with epilepsy unexposed or exposed prenatally to antiepileptic drugs: a meta-analysis of cohort studies. Drug Saf 33, 73-9. 
[54] Candelotti, E., De Vito, P., Ahmed, R.G., Luly, P., Davis, P.J., Pedersen, J.Z., Lin, H-Y., Incerpi, I., 2015. Thyroid hormones crosstalk with growth factors: Old facts and new hypotheses. Immun., Endoc. \& Metab. Agents in Med. Chem., 15, 71-85.

[55] Caravale, B., Allemand, F., Libenson, M.H., 2003.Factors predictive of seizures and neurologic outcome in perinatal depression. PediatrNeurol 29, 18-25.

[56] Carlé, A., P. Laurberg, P., Pedersen, I.B., 2006. Epidemiology of subtypes of hypothyroidism in Denmark. European Journal of Endocrinology 154(1), 21-28.

[57] Carlé, A., Pedersen, I.B., Knudsen, N., 2011. Epidemiology of subtypes of hyperthyroidism in Denmark: a population-based study. European Journal of Endocrinology 164(5), 801-809.

[58] Contag, S.A., Mertz, H.L., Bushnell, C.D., 2009. Migraine during pregnancy: is it more than a headache? Nat Rev Neurol 5, 449-56.

[59] De Vito, P., Candelotti, E., Ahmed, R.G., Luly, P., Davis, P.J., Incerpi, S., Pedersen, J.Z., 2015.Role of thyroid hormones in insulin resistance and diabetes. Immun., Endoc. \& Metab. Agents in Med. Chem., 15, 86-93.

[60] Eghbalian, F., Monsef, A., Taghdiri, M.M., 2007. Neonatal seizures: etiology and frequency. Iran J Child Neurology 39-42.

[61] El-bakry, A.M., El-Ghareeb, A.W., Ahmed, R.G., 2010.Comparative study of the effects of experimentally-induced hypothyroidism and hyperthyroidism in some brain regions in albino rats. Int. J. Dev. Neurosci. 28, 371-389.

[62] El-Ghareeb, A.A., El-Bakry, A.M., Ahmed, R.G., Gaber, A., 2016.Effects of zinc supplementation in neonatal hypothyroidism and cerebellar distortion induced by maternal carbimazole. Asian Journal of Applied Sciences 4(04), 1030-1040.

[63] EURAP Study Group, 2006. Seizure control and treatment in pregnancy: observations from the EURAP epilepsy pregnancy registry. Neurology 66, 354-60.

[64] Gilbert, M.E., Sui, Li., 2006.Dose-dependent reductions in spatial learning and synaptic function in the dentate gyrus of adult rats following developmental thyroid hormone insufficiency. Brain Res. Arch. 10-22.

[65] Haddow, J.E, Palomaki, G.E., Allan, W.C, 1999. Maternal thyroid deficiency during pregnancy and subsequent neuropsychological development of the child. New England Journal of Medicine 341(8), 549-555.

[66] Hamanna, I., Seidlova-Wuttke, D., Wuttke, W., Köhrle, J., 2006.Effects of isoflavonoids and other plant-derived compounds on the hypothalamus-pituitary-thyroid hormone axis. Maturitas 55S, S14-S25.
[67] Hogan, N.S., Crump, K.L., Duarte, P., Lean, D.R.S., Trudeau, V.L., 2007. Hormone crossregulation in the tadpole brain: developmental expression profiles and effect of T3 exposure on thyroid hormone- and estrogen responsive genes in Rana pipiens. Gen. Comp. Endocrinol. 154 (1-3), 5-15.

[68] Incerpi, S., Hsieh, M-T., Lin, H-Y., Cheng, GY., De Vito, P., Fiore, A.M., Ahmed, R.G., Salvia, R., Candelotti, E., Leone, S., Luly, P., Pedersen, J.Z., Davis, F.B., Davis, P.J., 2014. Thyroid hormone inhibition in L6 myoblasts of IGF-I-mediated glucose uptake and proliferation: new roles for integrin $\alpha v \beta 3$. Am. J. Physiol. Cell Physiol. 307, C150-C161.

[69] Jaigobin, C., Silver, F.L., 2000. Stroke and pregnancy. Stroke 31, 2948-51.

[70] Kawakami, T., Yoda, H., Shima, Y., Akamatsu, H., 2002.Incidence and causes of neonatal seizures in the last 10 years. No To Hattatsu. 24(6), 525-9.

[71] Klein, R.Z., Sargent, J.D., Larsen, P.R., Waisbren, S.E., Haddow, J.E., Mitchell, M.L., 2001. Relation of severity of maternal hypothyroidism to cognitive development of offspring. Journal of Medical Screening 8(1), 18-20.

[72] Koromilas, C., Liapi, C., Schulpis, K.H., Kalafatakis, K., Zarros, A., Tsakiris, S., 2010.Structural and functional alterations in the hippocampus due to hypothyroidism," Metabolic Brain Disease 25(3), 339-354.

[73] Lazarus, J.H., Bestwick, J.P., Channon, S., 2012. Antenatal thyroid screening and childhood cognitive function. New England Journal of Medicine 366(6), 493-501.

[74] Lockhart, E.M., Baysinger, C.L., 2007. Intracranial venous thrombosis in the parturient. Anesthesiology 107, 652-8.

[75] Manoel, R.R., Demelo, A.N., 2006. Comparative clinical study of pre term and full term newborn, neonatal seizures. Arq Neuropsiquiatr 64(1), 45-50.

[76] Noori, M., Dhanjal, M.K., 2011.Neurological disease in pregnancy. Obstetrics, Gynecology and Reproductive Medicine 21, 6.

[77] Pacheco-Rosado, J., Arias-Citalán, G., OrtizButrón, R., Rodríquez-Páez, L., 2005.Selective decrease of $\mathrm{Na}^{+} / \mathrm{K}^{+}$-ATPase activity in the brain of hypothyroid rats. Proc. West. Pharmacol. Soc. 48, 52-54.

[78] Pop, V.J., Brouwers, E.P., Vader, H.L., Vulsma, T., Van Baar, A.L., De Vijlder, J.J., 2003. Maternal hypothyroxinaemia during early pregnancy and subsequent child development: a 3-year follow up study. Clinical Endocrinology 59(3), 282-288.

[79] Santisteban, P., Bernal, J., 2005.hyroid development and effect on the nervous system. Reviews in Endocrine and Metabolic Disorders, 6(3), 217-228. 
[80] Scher, M.S., 2000. Seizures in the newborn infant: diagnosis, treatment, and outcome. ClinPerinatol 24, 735-772.

[81] Scher, M.S., 2003. Neonatal seizures and brain damage. PediatrNeurol 29, 381-390.

[82] Van Herck, S.L.J., Geysens, S., Bald, E., Chwatko, G., Delezie, E., Dianati, E., Ahmed, R.G., Darras, V.M., 2013.Maternal transfer of methimazole and effects on thyroid hormone availability in embryonic tissues. Endocrinol. 218, 105-115.

[83] Zamoner, A., Funchal, C., Heimfarth, L., Silva, F.R.M.B., Pureur, R.P., 2006. Short-term effects of thyroid hormones on cytoskeletal proteins are mediated by GABAergic mechanisms in slices of cerebral cortex from young rats. Cell. Mol. Neurobiol. 26, 209-224.
[84] Zoeller, R.T., 2004. Editorial: Local control of the timing of thyroid hormone action in the developing human brain. J. Clin. Endocrinol.Metab. 89 (7), 3114-3116.

[85] Zoeller, R.T., Dowling, A.L.S., Herzig, C.T.A., Iannacone, E.A., Gauger, K.J., Bansal, R., 2002. Thyroid hormone, brain development, and the environment. Environ. Health Perspect. 110 (Suppl. 3), 355-361.

[86] Zupanc, M.L., 2004. Neonatal seizures. Pediatric Clinics of North America, 51(4), 961978.

Citation: Ahmed R.G. Maternal Thyroid Disorders and Risk of Neonatal Seizure: Current Perspective. ARC Journal of Neuroscience. 2018; 3(1):21-25. doi:dx.doi.org/10.20431/2456-057X.0301004.

Copyright: (C) 2018 Authors. This is an open-access article distributed under the terms of the Creative Commons Attribution License, which permits unrestricted use, distribution, and reproduction in any medium, provided the original author and source are credited. 